\title{
AN OVERVIEW OF QUALITY AT STATE AND PRIVATE UNIVERSITIES
}

Hariz Agić1

Sead Rešić

Pedagogy Institute of Tuzla Canton

Faculty of Science, Univerzity of Tuzla

Received: 29.01.2012

Accepted: 22.02.2012
Original scientific paper
UDC: 378.057:378.014.3(497.6)

378.058:378.014.3(497.6)

\begin{abstract}
We are witnessing the emergence of private universities "like mushrooms after rain". It is more than clear that they are not well met by state universities. Bosnia and Herzegovina is a very fertile ground for setting this palette of problems in the educational focus of interest of the public, because there are no competent ministries of education at the state level. There is framework law on the state level but nothing exists anywhere along the vertical axis. This produced distortion of the quality and reputation of higher education. In this paper a survey among teachers and students of private and state university was conducted and has shown that there are differences in opinions of respondents in some respects regarding the quality of work. The solution would be replacing the stereotypical opinions about the differences between private and public universities and entirely rotating them toward a new, living approach to ensuring quality of education.
\end{abstract}

Key words: private and state universities, the quality of university education

\section{INTRODUCTION}

The current structure of Bosnia and Herzegovina has made it possible for universities to be established in certain environments and appear in a large number, but in other environments they are practically nonexistent, depending on whether a state university exists there, how powerful it is, as well as on presence of bracing between political elite and possible founders of the university. The situation in this are is more than chaotic.
There are claims and opinions that private universities are being completed without actual problems for students, regarding studying, with lesser demands, provided that school fees are paid regularly. On the other hand, state universities do not accept diplomas of students who graduated from private universities. This is the most prominent in procedures regarding elections for teaching profession, where masters and doctors of sciences are not welcome to state universities (Nezavisne, 2009).

1 Correspodence to:

Agić Haris, Pedagogy Institute of Tuzla Canton

Phone: +38761 109899

E-mail: agich59@hotmail.com 
The aim of this research is to examine opinions regarding quality of private and state universities. Based on the results, the problem of origin of ownership structure of universities would be attempted to become replaced with the problem of rotation towards quality, from defining and reaching it, to its follow-up and constant improvement of the work of universities, regardless of the type of ownership - the manner recommended by TQM-a (Total Quality Management) philosophy (Sallis, 1996). As previously mentioned, the issue of ownership of the universities should be replaced by the question related to quality.

\section{The issue of enrollment at university}

The research conducted among senior students in high schools suggests that most students (91\%) decide on enrollment at a state university, since those universities are state-funded, although some consider this fact with some reserve, because "students at state universities have to pay a great number of hidden costs throughout the year" (Press, 2010). Nevertheless, when these costs of studying at private universities are compared to costs of studying at state universities, it is clear that studying at private universities costs a lot more. There is a general opinion that this kind of studying is meant only for students with wealthy parents. Very often, the clients of a private university are students who also work and are "after a diploma in order to make their working positions more stable or even improve them at their respective organizations". There is also a belief that private universities are a destination meant for unsuccessful ex-students from state universities, or are highly positioned persons (or their descendants) with strong ambitions in social and political life. On the other hand, private universities, although more expensive, offer more flexible programs to their students, and those can not be found at state universities. Private universities are more oriented towards the needs of the market, so students enroll there hoping to be more successful in search for suitable employment. They are established in areas where there are no state universities and are welcomed by students from local surroundings, since the cost of studying is equal or lesser than the cost of studying at state universities in more distant centers.

\section{Quality of studying - research}

Aresearch performed by Infostud among high school graduates, in which 2192 graduates participated and over half of them were exquisite student, almost $75 \%$ of examinees believes that private universities offer more practical knowledge. "Professional practice is also an advantage at private universities. When it comes to the expertise of teachers, examinees do not note significant differences. Advantage lies with private universities also in compliance with Bologna Declaration, as well as in studying equipment and teaching conditions" (Ćetković, Vreme no. 1029, 2010). Infostud's research shows that graduates from high schools believe that communication with teachers is much better at private universities than at state universities. These claims have been confirmed by our research as well. In another conducted research among students at private and state universities in Sarajevo Canton (Mehmedić-Džonlić, 2011), both groups were asked the same questions as to compare the attitudes of students who come from completely different studying environments. "Everyone takes what they want" was the bitter mutual attitude of students in all universities, which was also confirmed in our research. Students at state universities have 
nothing against the concept of private universities, but believe that such institutions are simply not on the same quality level as those abroad (Mehmedić-Džonlić, 2011). Examinees in this research confirmed that «the perception of private education in Bosnia and Herzegovina comes down to assumptions regarding purchasing a diploma since these universities "grow like mushrooms" and serve well to those who complete their studies through means of lesser effort because they did not succeed at state universities, and therefore represent social institutions for purchasing social peace, or students simply believe in the popular prejudice "if it is expensive, it must be good" when enrolling in a private university» (Mehmedić-Džonlić, 2011).

The essential questions, those which management structures of all universities should ask themselves, are some of the following: Do students, upon graduation from university, get employment?; What are their qualities in the workplace, according to employers?; Are students satisfied with the quality of service by teaching staff (regularity of classes, quality of classes, transparency and participation in grading)?; Is scientific research being worked on and are students involved in that segments of university life?; Are students involved in planning the exam terms and quality of grading?; Can they approach teachers for consultations and do they have possibility to see the exams upon grading?; Is the university amiable for collegial climate and what kind of environment is established for studying?; Are the study programs licensed and acceptable in European surrounding?; What is the relation toward application of Bologna process?

Above-mentioned questions determine a significant portion of area regarding quality of work in a university. This research will partially cover some of them.

\section{Stereotypes present in relation between private and state universities}

As opposed to Europe and USA, in Bosnia and Herzegovina there is still a dilemma - private or state university. According to the opinion of experts, this dilemma does not exist because there is enough space for both, fair play in competition can only be useful to students (Vreme, 2010). There is an overwhelming impression that certain members of academic community, who actually have no competition in their field of activity, stubbornly decline to operate in an academic community based on competition. Those persons have settled in, in due time, empowered their position through various elections, laws, legal acts, rules etc. As a matter of fact, the core of the problem is whether there is a concept which would enable a complete overview of quality and understanding of the concept "private". Stereotypes which are being fostered among students usually arise due to absence of any kind of contact and mutual exchange of experiences. Both types of students believe that they can not affect the situation at hand and that they have a shared responsibility for this (Mehmedić-Džonlić, 2011). One of the stereotypical opinions directed at private universities is the hyper-production of diplomas. However, Jovanović (2011) believes that this is present both at state and private universities, emphasizing that there are significant differences amongst universities, which can be confirmed according to the number of diplomas issued during one year (Jovanović, 2011). This author also claims that there are differences in a multitude of elements, including quality, but this is not gradable on a general level. He elaborated on this through these facts: state universities have long traditions, far greater number of teaching staff, so that this quantity leads to a greater number of quality 
teachers; state universities are supported by the state infrastructure, while with private ones this infrastructure is still being built; and that in some state universities there is weaker quality regarding teachers, as well as regarding the quality of classes, student books and equipment. This author also points out that in certain state universities which have a lot of financial resources at their disposal, money is being easily spent - on continual journeys abroad, on manufacturing various construction and similar engineering, costs are being oversized etc., while at private universities the matters are reversed since they are compelled to be more cautious regarding costs and saving money. The abovementioned author extrapolates a general appraisal - state and private universities are different. State universities are stronger, have existed for a longer time, have their traditions and are more trusted. Private universities are only beginning to grow and still suffer from "children's ailments". Some people established universities only in order to become certified teachers. Certain tycoons, according to him, who are in no way related to education, established universities in order to gain profit in that area as well, a maybe even to "launder money" (Jovanović, 2011). Still, this author, taking into account incipient weaknesses in establishing a private university, bespeaks that "the fact that in the West private universities have a long tradition and are significantly better and more expensive than state ones only points to the assumption that we, too, must be more patient with private organizations for higher education - let them develop faster and more efficiently. Of course, only in areas where there is a need for certain professions and human as well as other resources that can enable it" (Jovanović, 2011).
State universities are in advantage, and will hold advantage in the future, because the state takes care of them. The state shows its interest in specific profiles of expertise through state universities, that is, it finances those profiles which are necessary from the point of view of the state's interest (Vreme no.1029, 2010).

On the other hand, advantages of attending private universities are emphasized through everyday, immediate contact with teachers. Study groups are smaller, which at the very beginning means greater quality of the teaching process (Press, 2010). This was confirmed in our research as well.

Still, we are bearing witness to the concern of state universities students regarding jobs they can perform, professions and diplomas they acquire, the disappointment they feel even before completing their studies, and also the impression that they are a bit powerless regarding the perception of their future employers. This concern is even more prominent with students at private universities, especially considering the fact that employers show even greater distrust towards them. They are often not even given an opportunity to apply for certain jobs, because employers strictly define which kinds of diplomas are taken into consideration in administrative competitions. This means that universities, regardless of ownership structure, should be more directed towards the needs of employers of all sorts, with respect to pragmatism and acquisition of practical professional competencies during studies.

It can be concluded that state universities lean on the old system of work, multidecennial experience and affordable cost of studying. Some private universities offer advanced programs, superb teachers and a great future in the world, and some 
a manner to acquire a diploma fast and easily. All this is a prediction that in Bosnia and Herzegovina there will be struggle for each and every potential student, at least until Bologna process is applied everywhere and equally as a framework for the good path of every university's work, regardless of their ownership structure (Bošnjak \& Mecan, 2008). The problem of state universities, as seen by students attending private ones, apart from spreading corruption, is also large quantity of students, which affects the quality of teaching process, because at private universities students work in smaller groups and have a better relationship with their teachers, which was also confirmed by our research.

\section{METHODOLOGY OF RESEARCH}

The aim of research in this paper is to identify the intensities of standpoints of examinees, students and teachers at state and private universities about determinants of quality for those studies, and to determine whether there is significant difference in opinions among examinees withing the two groups. Accordingly, the following hypothesis was set: " $A$ difference exists in the intensities of standpoints between examinees at private and state universities regarding certain determinants of quality".

The sample of participants in this research consisted of first-year students at faculties for educational sciences (Department of Elementary School Education), 136 of them (65 at state university and 71 at private university), who attend classes using the same syllabus and same methodology (Bologna), and 15 of their teachers as well as 16 teaching assistants. In this research a survey was used which Mužić (1999, p. 82) equals with "a procedure of simultaneous and written data acquisition from a larger number of people (examinees), about something they know, feel or think". Survey was conducted via questionnaires comprising six questions on the Likert sale. The questionnaire covers six areas of quality, from regularity of classes, quality of classes and grading, to a proposal for improvement of work of the university.

\section{Data analysis}

In this research AVM (Average Value Method) method was used (Walker, 2006). This method was applicable after the four-degreed Likert scale of assessment of attitudes was functionally connected to numeric values from 2 to 5. Mark 2 signified the lowest, while mark 5 signified the highest level of satisfaction. Upon acquisition of structure of replies from 2 to 5 , it was possible to calculate the arithmetic mean of values of satisfaction in answers to every question or subquestion and for all three populations in both groups. Acquired average values were effectively perused to register differences in levels of expressed satisfaction of examinees according to the same questions. Those results are shown in tables and graphs. It was manifested that the usage of average values method was the most effective in recording differences in attitudes of examined populations. 


\section{Constancy in performance of classes and exercises}

An insight into results which encompass average values of satisfaction intensity regarding constancy of classes and exercises (due to voluminousness they are left out in this paper) shows that, related to this matter, students at private universities $(\mathrm{P})$ are more satisfied than their colleagues at state universities (S) for $0.06(4,15-4,09=+0,06)$.

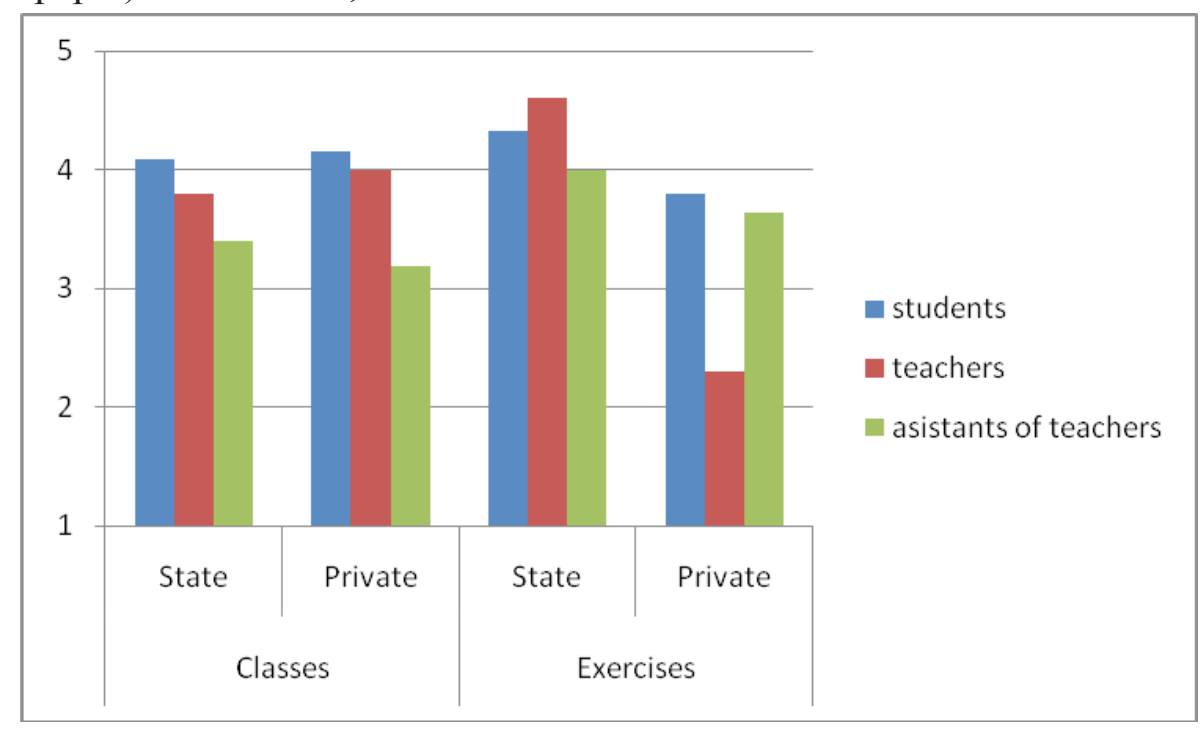

Figure 1. Attitudes of examinees regarding regularity of classes and exercises

Similar is the opinion of teachers, whose satisfaction with regularity of classes is for 0.2 higher of that by teachers at state universities. Teacher assistants have a different opinion. Those at state universities believe that classes at their universities are more regular. When it comes to exercises, all examinees in S group (Students: +0.52, Teachers: +2.3, Teacher Assistants: +1.37) share a greater level of satisfaction with regularity of exercises at state universities. In free comments from an open question, there are opinions such as: "I am satisfied with teacher assistants and exercises, but there are almost no classes, and this is very important to us because in the end we do no know what exactly to learn for the exam."

\section{Quality of classes and exercises}

Through insight into acquired average values, it is visible that students in group $\mathrm{P}$ are more satisfied with quality of classes with their teachers (-0.58). On the contrary, teachers in group $\mathrm{S}$ believe that their classes bear much morequality $(+1.1)$. The sameapplies to teacherassistants in group $\mathrm{S}$ who believe that their teachers work better than those in group $\mathrm{P}(1.0)$. When it comes to exercises, students from group $\mathrm{S}$ have a better opinion about exercises with their teacher assistants $(+0.11)$. Similar is the opinion of both teachers $(+2.2)$ and teacher assistants $(+1.31)$. It is possible to deduce some conclusions from students' open comments (group S): "I am not satisfied with the work of some teachers and teacher assistants" or "Teachers and teacher assistants could be more accessible to students" or "Certain teachers and teacher assistants are not capable of adequately transferring knowledge to students, orientate them towards work and extrapolate the maximum of their knowledge." 


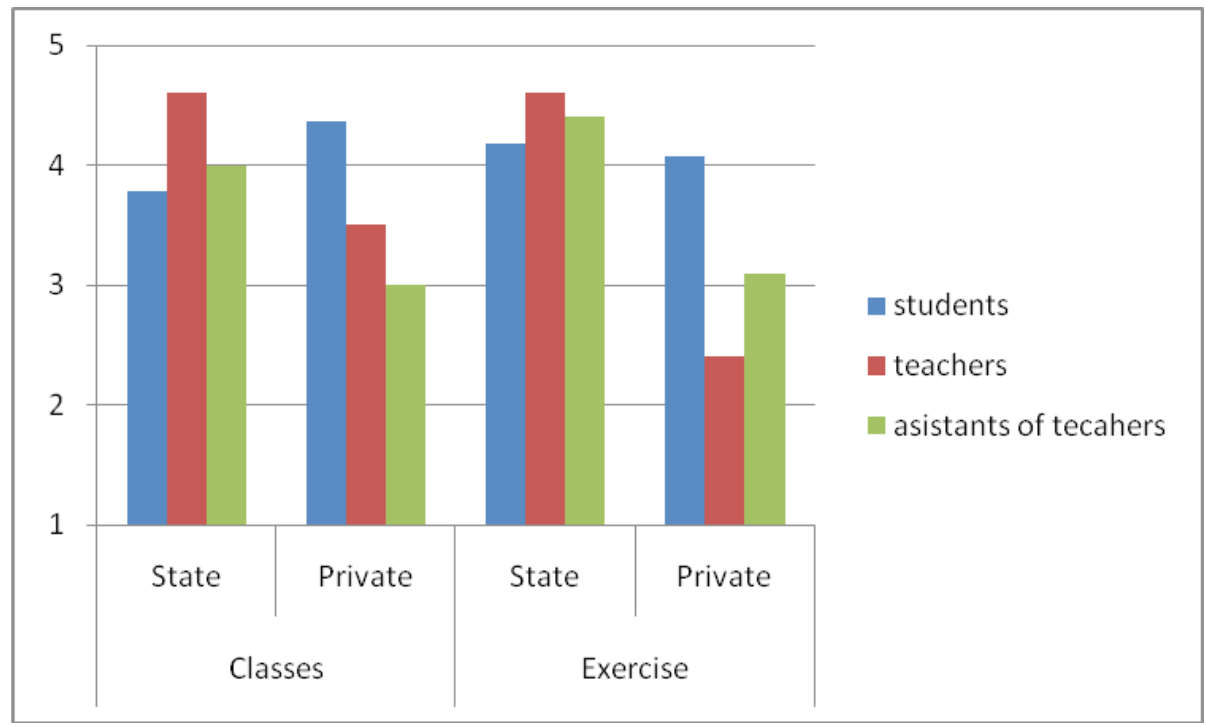

Figure 2. Attitudes of examinees regarding quality of classes and exercises

Acquired data points to the fact that at state universities, teachers and teacher assistants do not perform (or rarely do) self-evaluation based on students' attitudes.

\section{Interaction in classes and exercises}

The data shows that students at private universities are more satisfied with their participation during classes (-0.49), similar is the opinion of teachers (-0.6), while teacher assistants have almost the same attitude about students' activity at both types of universities, with small tendency towards group $\mathrm{S}$ students' benefit $(+0.061)$. When it comes to exercises, students in both groups have almost the same intensity of attitudes regarding activity in exercises $(+0.02)$.

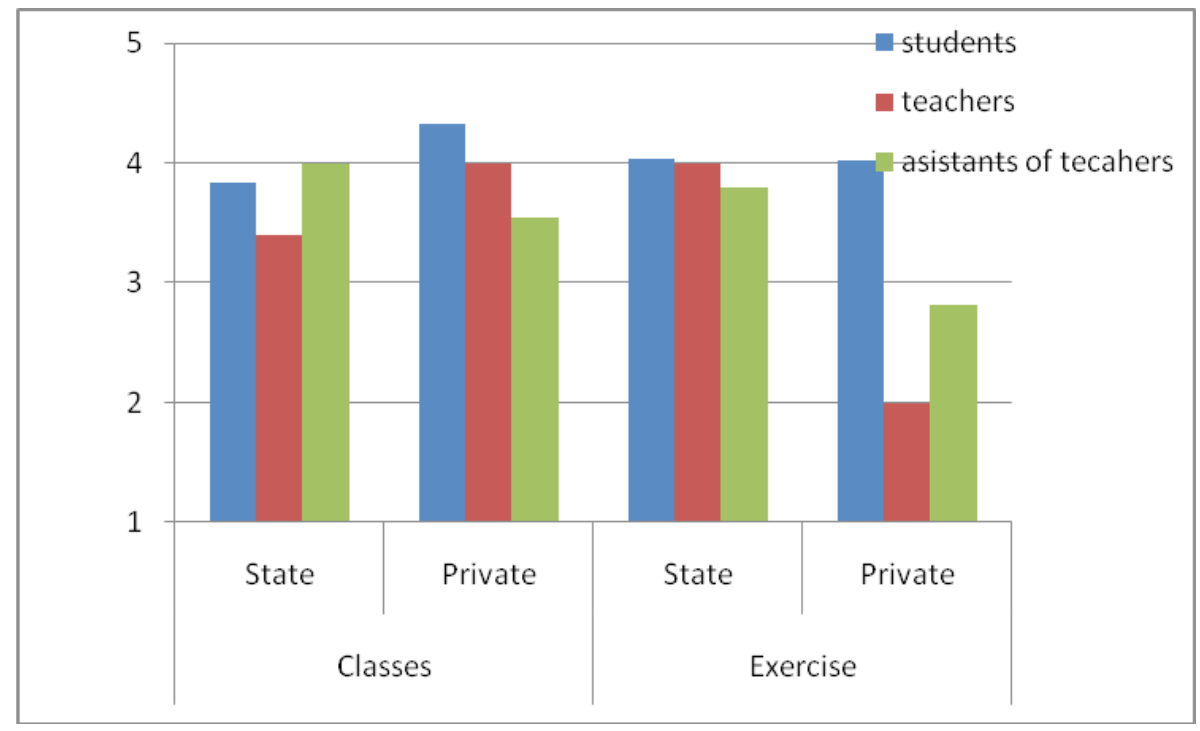

Figure 3. Attitudes of examinees regarding activity of students during performance of classes and exercises 
Students believe that quality would be somewhat better if the number of students in a group were lower. According to their opinion, "the number of enrolled students should be lower in order for teachers to devote more attention to individual students" (from the Questionnaire). Teachers and teacher assistants from $\mathrm{S}$ claim with greater certainty that students in their universities are more active during exercises $(+2,0 \mathrm{i}+1,01)$. Students from $\mathrm{S}$, regarding their participation in classes and exercises, believe "that every activity by students should be recorded in their indexes". "There should be more interaction between students and teachers, as well as with teacher assistants. Teachers should allow students to look at their written exams after grading because, after all, people learn from their mistakes, so it is easier to learn when they can see where they made mistakes in the exam" (from the Questionnaire). On the other hand, there are more students from P who claim: "I was jubilant with the positive relation teacher - student, teachers are very communicative and open for discussion".

\section{Grading the results of students' studying}

The fourth area of research is connected with grading, as a very important segment of the teaching process. This was covered by five indicators. The first claim (a) refers to the existence of "clear criteria which everybody is familiarized with at the beginning of the academic year". Students from $\mathrm{P}$ have a more positive attitude regarding this question $(-0.32)$, while members of both groups of teachers share their attitude about criteria transparency and grading rules $(0.00)$. Teacher assistants from $\mathrm{S}$ have a stronger attitude regarding this in comparison to their colleagues from $\mathrm{P}(+1.07)$. (Graphs $4-6)$

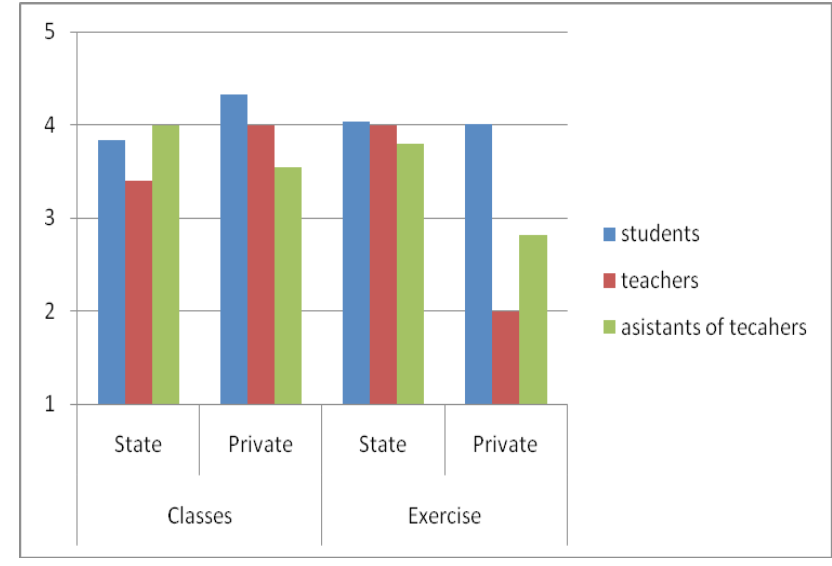

Figure 4. Attitudes of students regarding grading

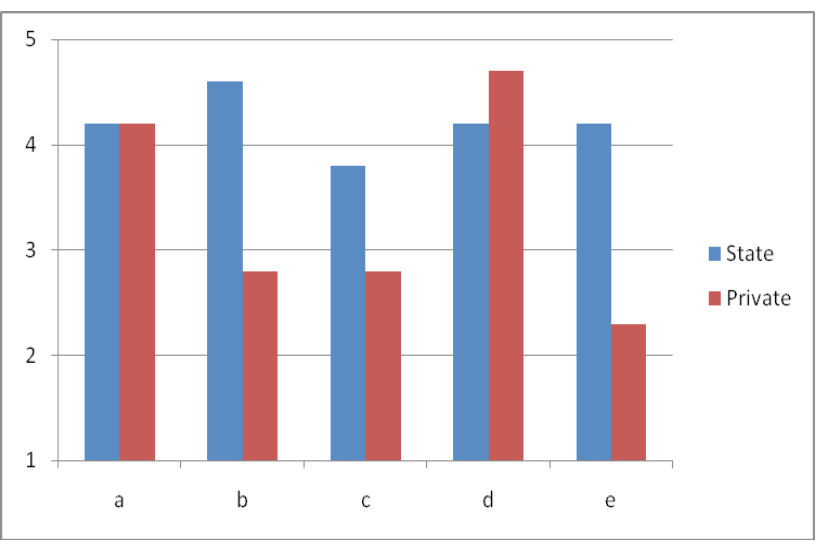

Figure 5. Teachers' attitudes regarding grading

Considering the claim (b), that "everybody grades in their own way", students at state universities are at a greater advantage. Stronger agreement with the claim that everybody grades in their own way: students $(+0.19)$, teachers $(+1.8)$ and teacher assistants $(+2.02)$ at state universities, states that this occurrence is more present at state universities, i.e. this is in a direct connection with greater intensity of attitudes in $\mathrm{P}$ about existence of clear rules about grading, as prescribed by Bologna. Here are some statements from S: "Some teachers do not grade knowledge, but let students pass by their own personal choice", "Partial exams are a far better way of grading in comparison with only one final exam". Students in P: "All teachers should work according to standards assigned to them while signing their job contract in the 
university, and not apply their own standards" (from the Questionnaire). Students in both types of universities point out the omissions regarding various approaches to grading. All of them emphasize their wish to include and implement agreed-upon rules regarding grading.

When claim (c) "Students participate in formation of the final grade" is concerned, students at private universities display a more prominent occurrence of mutual formation of the final grade (-0.39). Teachers and teacher assistants at state universities believe that mutual formation of the final grade is an adopted value at university culture (T: +1.0 , T.A.: +0.2$)$. Formation of the final grade is closely connected to transparency in grading. It depends on the existence of interaction on relation teacher / teacher assistant, teacher and teacher assistant - students. There are vast possibilities for improving the teaching process and overall satisfaction of students with quality.

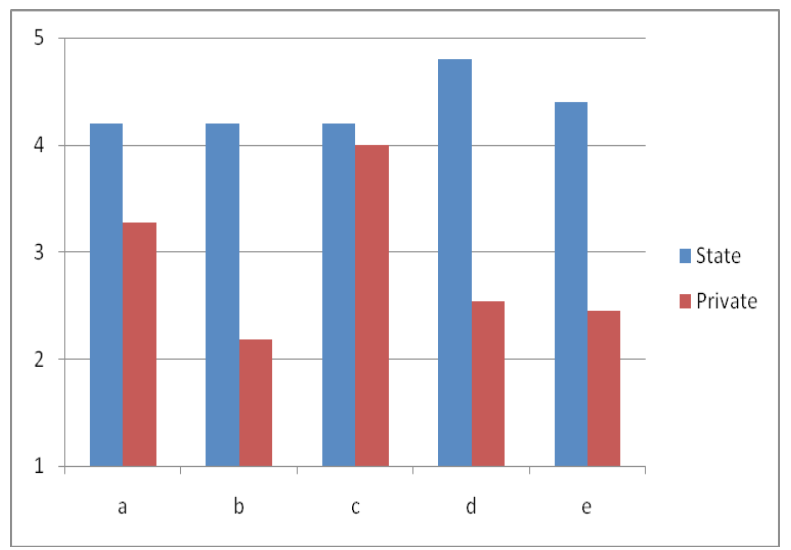

Figure 6. Attitudes of teacher assistants about grading

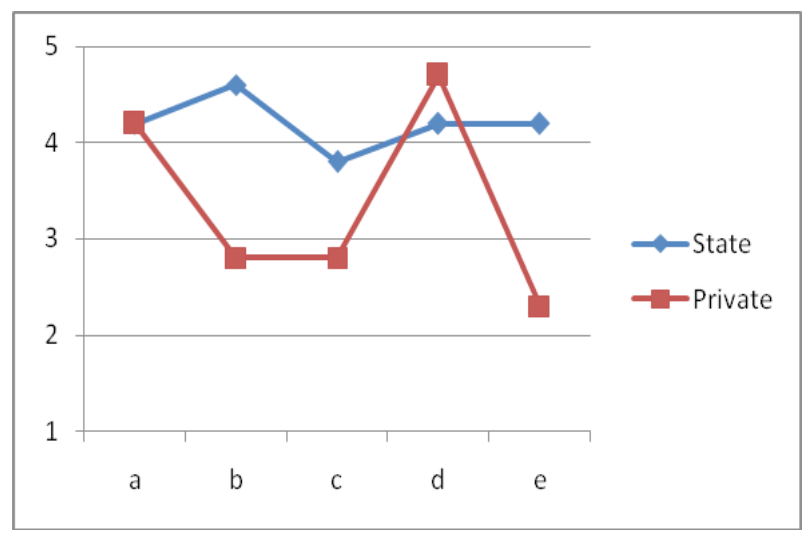

Figure 7. Attitudes of teachers about grading
Considering claim (d), "Students may without problems see their exams after grading", the research has shown that only students in $\mathrm{P}$ are satisfied with this occurrence (-0.88), confirming thereby statements that students gave in their free comments, as well as complementarity with distribution of responses regarding mutual formation of the final grade. Both these indicators show that at private universities students can more frequently see their exams without the fear of something unexpected happening. Similar is the claim of teachers as well $(-0.5)$, while teacher assistants at state universities claim that they are more engaged in giving students the opportunity to see their exams. This is understandable, since most exams at state universities are conducted by teacher assistants, except for the final exam. Students are very sensitive regarding this issue. They are hurt very much by feckless attitude of some teachers and teacher assistants who disapprove of students' claims to see their exams, which then creates suspicions regarding correctness of the grading process. Both subjects have something to improve in this case.

The final indicator that covers the area of grading is (e) 'For all students' questions, teacher assistants/ teachers are very approachable and communicative. Insight into data clearly shows that approachability and communicativeness are more frequently found at private universities $(-0.50)$. Teachers and teacher assistants in $\mathrm{S}$ think differently: they believe (T: +1.9 and T.A.: +1.95$)$ that approachability is one of their virtues. Due to the large sample and the fact that students are clients in an educational service, their opinions should be taken as more relevant. The following was confirmed through students' statements in free comments: "Teachers and teacher assistants (at state universities) could be a bit more available and approachable 
to students" (S), "Bologna is being conducted only by a certain number of teachers and teacher assistants, who are always available to students" (4) (S), "Some teachers do not grade knowledge, but rather let students pass exams by their own choice" (S). Students at private universities are more moderate. They claim: "All studying conditions and communication with teachers are satisfactory", "I was pleasantly surprised by the positive relationship on the level teacher - student, teachers are very communicative and open for interaction", "I am very satisfied with studying in this university", "No comment, because every comment would be redundant". According to this, it follows that students from $\mathbf{P}$ are more satisfied with their teachers and teacher assistants when it comes to communicability and accessibility.

\section{Bologna process.}

The area regarding Bologna process is also covered through five indicators. The examinees (a) were asked whether they are clear about the approach to studying according to Bologna. As is was in earlier cases, there is a difference in opinions of students and their teachers and teacher assistants. While students in (P) find Bologna "more clear" (-0.49), teachers at state universities believe that same is the case in their universities (T: $+0,1$. T.A.: $+1,91)$.

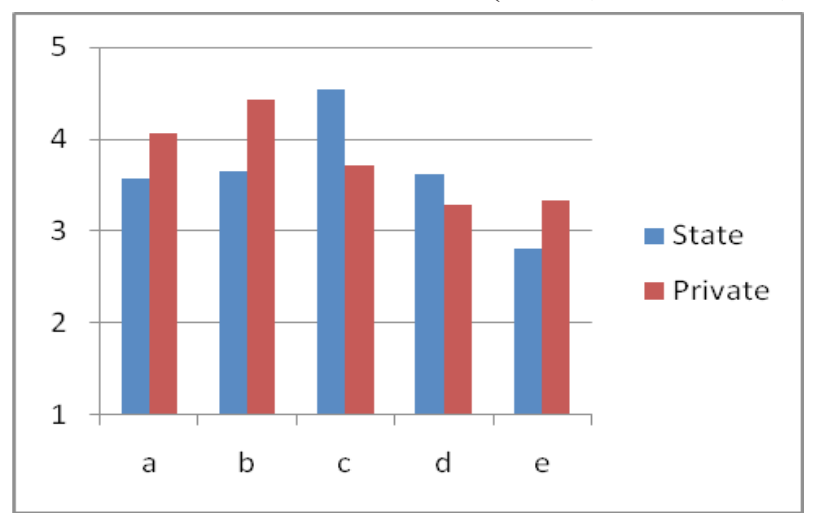

Figure 8. Attitudes of students about Bologna

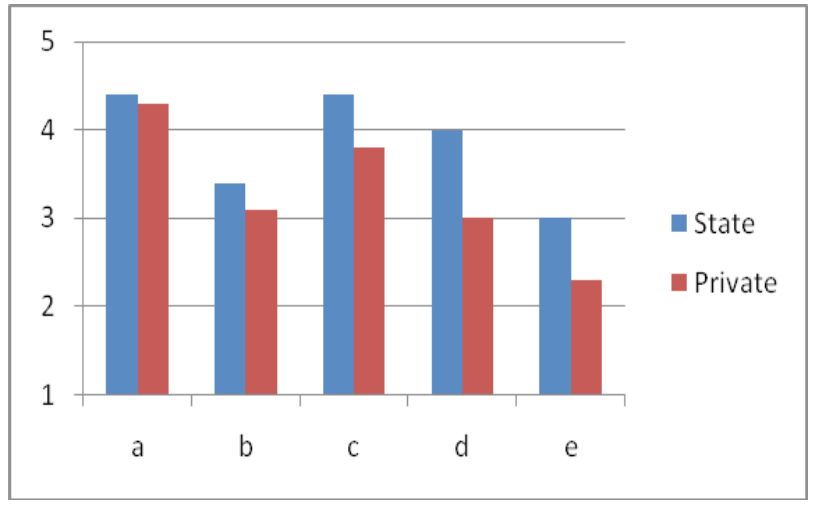

Figure 9: Attitudes of teachers about Bologna

The claim (b) "We do not have fulfilled conditions necessary for Bologna" is better accepted with students in P(-0.79). Teachers and teacher assistants in $\mathrm{S}$ expressed stronger attitudes about the fact that the conditions have not been formed for application of Bologna (T: $+0, .3$ T.A.: $+0,7)$. Students in $\mathrm{P}$ are aware that equipment and organization of the teaching process at universities do not follow the requirements for Bologna.

Students in $\mathrm{P}$ have, regarding this, expressed their free comments: "I disagree with the fact that parttime students also have classes on weekdays, at least they should have two classes or exercises at a tine. Thank you", "Without consulting with the students, certain exam terms for some subjects were dismissed and classes are scheduled in the same time for full-time and part-time students", "I do not like the fact that classes start early and finish late in the year". 


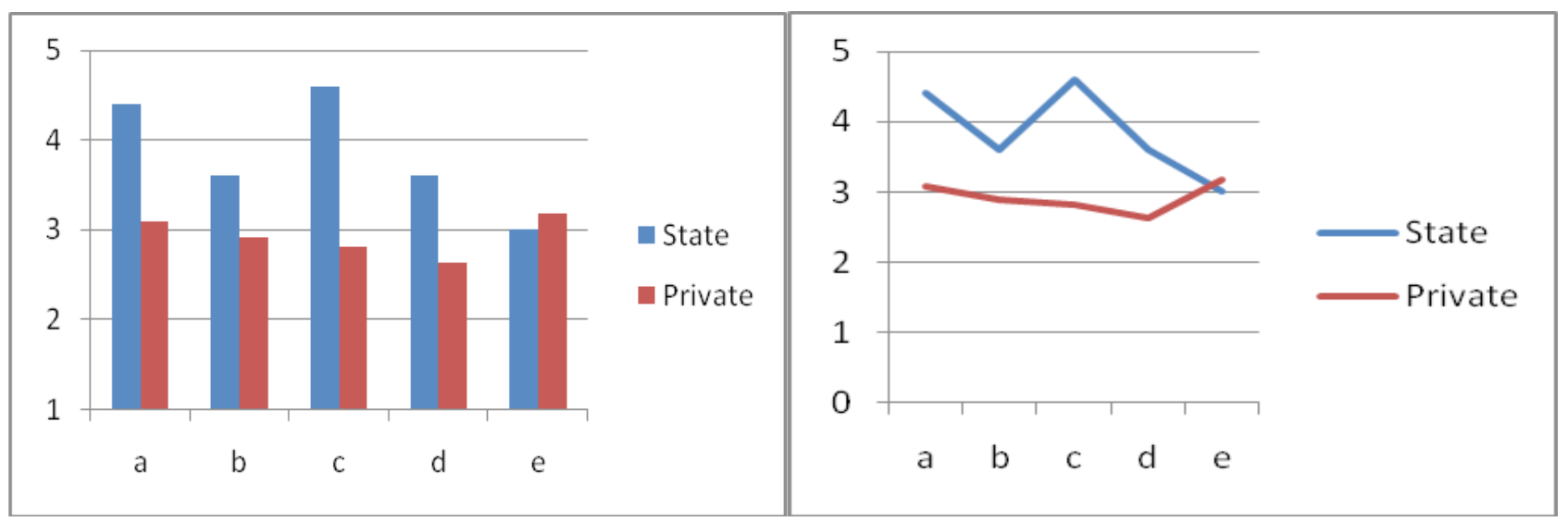

Figure 10. Attitudes of students towards Bologna.

However, considering the statements of students

It can be concluded that students in $\mathrm{P}$ are not satisfied with tendencies of private universities to gain more financial assets while investing less resources. One of the possible reasons for this outcome is that teachers, and especially teacher assistants, are very much burdened with obligations prescribed by Bologna. They care about leading the implementation of Bologna to it's full capacities, so that their lives could be more bearable.

Both groups of students were in accordance with clam (c) Everyone interprets it in their own way - students believe that everybody implements Bologna in their own way. Still, examinees from $\mathrm{S}$ group were in greater accordance that Bologna is interpreted subjectively and is being implemented mostly to the detriment of students. This is visible in the table representation as well. The intensity of attitudes is in favor of examinees in $\mathrm{S}$ group with greater agreement that Bologna is understood subjectively and is implemented mostly at the cost of students. This can be seen in table representation. Intensities of attitudes are in favor of examinees as follows: $\mathrm{S}:+0.82$, $\mathrm{T}:+0.6$, T.A.: +1.79 . The conclusion is more than obvious: there is more disorder regarding misunderstandings, or better said, avoiding Bologna, at state universities. at private universities, such as: "Many teachers do not follow Bologna and do everything as per their individual opinions", "The greatest remark is that every teacher interprets Bologna in their own way", "All teachers should work in accordance with standards given at the time of their signing the job contract at the university, and not in their own way", it can be concluded that in both types of universities there is a lot to be done about the issue of transparency.

Considering the claim (d) "Bologna is used in ways that are at students' cost", the intensity of complete accordance is on the side of $\mathrm{S}$ group examinees $(\mathrm{S}$ : +0.33 ; T: 1.00 ; T.A.: +0.97 ), which may lead to the conclusion that there is more disruption in Bologna application at state universities and that this change is poorly accepted there. Results of this indicator are in agreement with results from the previous one, which is logical and expected.

The final indicator which covers the area of Bologna implementation is in the form of claim (e) "Students' association was formed according to Bologna". Higher level of agreement with this claim on lies on the part of students and teacher assistants at private universities (S: -0.54; T.A.: -0.18), while teachers believe that at state universities students' associations were formed according to Bologna $(+0.7)$. 
They think that it is "natural" for students in S group to be more organized. Certainly, both types of universities should work more seriously on organizing students in their respective universities, since Bologna is based on active participation of all stakeholders.

\section{Suggestions for improvement of quality at university}

Final, but also the most important area of quality is related to attitudes about suggestions for continuous improvements of quality. This, alongside with measuring quality according to certain standards, meeting those standards, is the most significant part of quality. The issue is even more delicate when the quality of such an important service such as high education is in question. This area is covered through eight claims, that is, suggestions for improvement of quality of work at universities. With the first claim (a) "There needs to be more communication with teacher assistants and teachers" examinees in group $\mathrm{S}$ agree more $(\mathrm{S}:+0.37$; $\mathrm{T}:+1.00$; T.A.: +1.88 ), which can mean that communication in all these relations is insufficient, which is compatible with results from the third area about interaction on the plane teachers - students. Students in group P suggest: "A more precise and forward work of teachers and teacher assistants", "All working conditions and communication with teachers are on a satisfactory level", while those in S suggest: "I believe that the number of enrolled students should be lower, so that teachers can devote more attention to individuals. If we are implementing Bologna, let it work in the real sense of the word". "We need a regular and accessible timetable", "Timetable should be improved so that the break between classes does not last for five hours".
It is clear that both types of universities have the necessary space for including a more efficient two-way communication based on the power of argument and mutually reached decisions.

The suggestion (b) "Using various teaching methods" is more desirable for examinees in group S (S: +0.63; T: +1.4; T.A.: +1.88), which

leads to the conclusion that classes for group $\mathrm{S}$ are more traditional, lacking the usage of innovated approaches, which is in accordance with the lack of interaction from the third section of examined quality. The above-mentioned claim is directly dependent on the necessary pedagogical support for teachers and teacher assistants in segments of application of a broad spectrum of teaching methods. Obviously, state universities should make significant changes in this area.

With the suggestion (c) "It is necessary to include clear rules of grading students' knowledge and make them known from the beginning of education", as expected, examinees in group $\mathrm{S}$ agree more $(\mathrm{S}$ : +0.75 ; T: +0.8 ; T.A.: +1.79 ). In favor of this, there are students' statements: "The schedule of classes and exams should be standardized afore-hand so that students are informed as early as possible", "All students are different and should be treated like that. Students who do not work hard have easier pass than those who work hard".

It can be concluded that both types of universities lack more attention regarding planning and informing students in due time. As it is, this problem is prominent at state universities as well. 


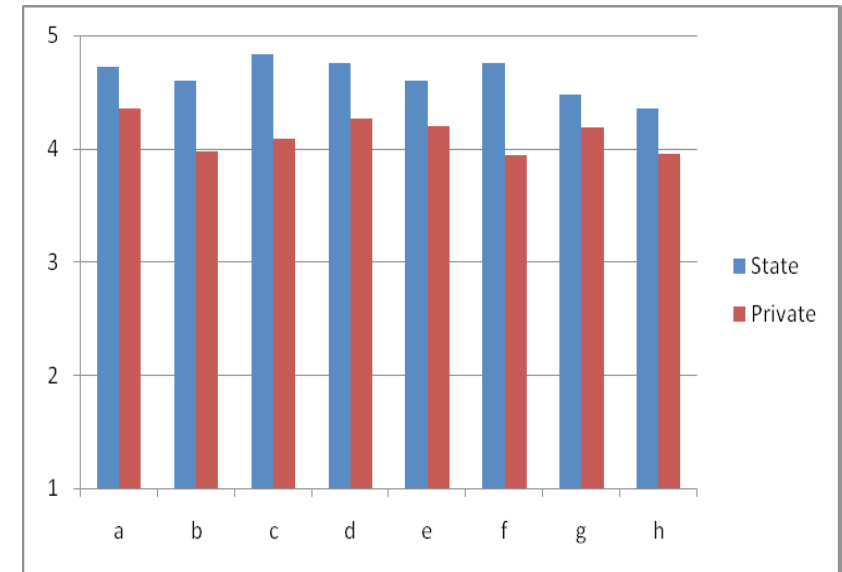

Figure 11. Students'attitudes about improvements

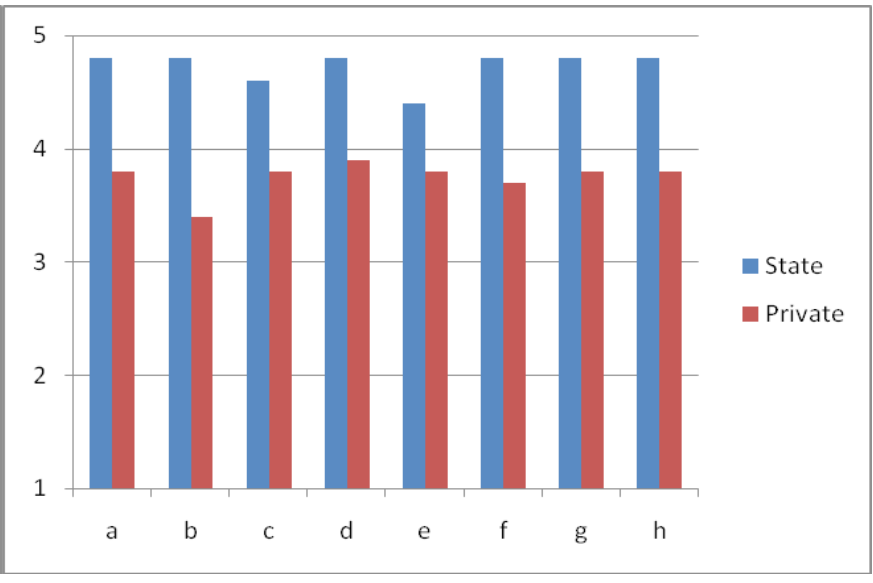

Figure 12. Teachers' attitudes about improvements

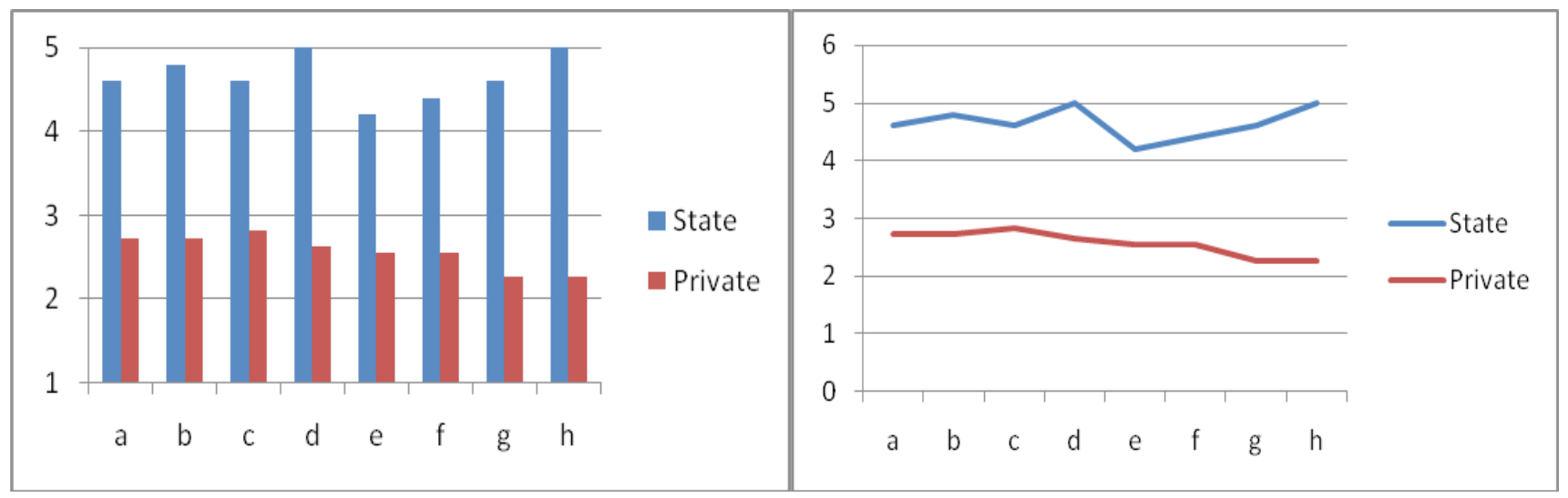

Figure 13. Attitudes of teacher assistants regarding improvement of quality

The same as in previous indicators in this area, this claim (d) "Exam terms and dates should be agreed upon mutually by students, teacher assistants and teachers" also yields more need for fulfillment with examinees in group S $(\mathrm{S}:+0.41$; $\mathrm{T}$ : +0.6 ; T.A.: $+1.64)$. This is expected, considering the results from other compatible areas of quality. So, more work needs to be done regarding planning activities involving conducting classes and evaluating the results of studying. Generally, this must be a priority for all universities, but research suggests that state universities have more work to do.

Grading was talked about in section 4, which is the reason why results of measuring attitudes toward the suggestion (e) "It is necessary to grade expected knowledge and not ignorance" are significant. Considering the results in section 4 , it is logical that the need for fulfilling this claim are more prominent in examinees from group $\mathrm{S}$ (St: +0.49 ; T: +0.9 ; T.A.: +2.37). Therefore, there is need for intervention here too, as well as for the support of pedagogy and didactics. Improvement in this area can raise the level of quality much higher. Finally, according to students' statements, the following issues have surfaced: "Questions in the final exam should not be posed from footnotes" (from the Questionnaire). There is space for improvement at all universities, according to the definition of quality, but this is more prominent at state universities.

Indicator (f) "Teachers and teacher assistants should be more accessible for the needs of students" was discussed earlier in section 3. Students' statements, especially of those in $\mathrm{S}$, show that accessibility 
lacks more at state universities ( $\mathrm{St}:+0.29$; $\mathrm{T}$ : +1.0 ; T.A.: +2.33). As in previous cases, it is also visible here that more attention should be paid to implementation of "student in the center of attention" philosophy at state universities.

The necessity (g) that "Teachers and teacher assistants should possess developed pedagogical skills needed for quality performance in classes" is, expectedly, more prominent in group $\mathrm{S}(\mathrm{St}:+0.40$; $\mathrm{T}$ : +1.0 , T.A.: +2.73 ). This need is directly connected with successful confrontation with teaching methods and application of various assortment of grading techniques for students' studying results. Therefore is is obviously necessary to include obligatory pedagogical support for teaching staff at universities, especially for non-educational departments.

The final indicator in this area is claim (h) "Various methods of assessing results of students' learning should be implemented", which is similar to claim (c). In this case also, there is a more intensive need for this indicator by examinees in group $\mathrm{S}$ ( $\mathrm{St}:$ : +0.81 ; T: +1.1 ; T.A.: +0.86 ). Fulfillment of this claim is in close relationship with that of claim from indicator $(\mathrm{g})$. This is one of the major changes the Bologna process has brought on. Therefore, it is obligatory for all universities, but, in this case, it is a priority for state universities.

\section{CONCLUDING CONSIDERATIONS}

In this research some of the quality area were observed. In short, only one part of determinants of quality of work at universities was examined, and it covers:

1. Regularity of the teaching process;

2. Quality of the teaching process;

3. Participation of students in classes;
4. Grading students' studying results;

5. Understanding and implementation of the Bologna process;

6. Willingness to make changes and constantly improve the universities' work.

The following can be noticed from acquired data analysis:

1. Students at private universities $(\mathrm{P})$ are more satisfied than their colleagues at state universities (S) for $0.06(4,15-4,09=+0,06)$. Similar is the opinion of teachers, whose satisfaction with regularity of classes is 0.2 higher than that of teachers at state universities. Teacher assistants have a different opinion. Those at state universities believe that classes at their universities are more regular. When it comes to exercises, the situation slightly differs. All examinees in S (students +0.52 , teachers +2.3 , teacher assistants +1.37) share a greater level of satisfaction with regularity of exercises at state universities.

2. Generally, when it comes to quality of classes and exercises, students in $\mathrm{P}$ are more satisfied with the quality of their teachers' classes $(-0.58)$, while students in $\mathrm{S}$ have a better opinion about exercises with their teacher assistants $(+0.11)$. Teachers and teacher assistants at state universities believe that classes and exercises at their universities have more quality.

3. In the matter of students' participation or activity in the teaching process, students and teachers at private universities share a more positive attitude about activities of students in classes, while regarding the quality of exercises there are almost identical agreements among students, even though teachers and teacher assistants at state universities believe that exercises at their universities have more quality when it comes to students' participation in their realization. 
4. Grading is in the center of students' interest. This are is covered through five attributes, which are represented in more detail above. For almost all attributes, there is greater agreement at private universities, except for the claim marking "that each teacher grades in their own way", the intensity of which is stronger at state universities.

5. This are covers the issues and understanding of the Bologna process. Bologna is "more clear" to students in group P $(-0.49)$, while teachers at state universities believe that this is the case at their universities (T: +0.1 ; T.A.: +1.91$)$. However, the claims that Bologna is being implemented by everyone in their own way and is being exploited mostly in ways that do not benefit students are better founded at state universities. In short, Bologna is much more positively perceived at private universities.

6. The final area of quality is involved with readiness and suggestions for improving quality. It is covered through eight indicators. It is symptomatic, but also expected, that all examinees at state universities have a stronger need for concrete measures for improving quality. This may mean that the situation at state universities is more "squalid" and that there is a strong need for change of the situation. On the other hand, it could be concluded that only those who are inclined towards constant improvements are in favor of this process. Most certainly, the first option is more realistic.

The claims which cover the first five areas of quality are more stable at private universities. Taking the above-mentioned into consideration, it can be concluded that "there is a difference in the intensities of attitudes with examinees at private and state universities about certain landmarks of quality", which confirms the set hypothesis. It could also be concluded that quality is on a higher level at private universities than it is on state ones. However, the question is whether the choice of areas of quality would be enough to make such claim valid. Based on this research, and researches conducted in other areas, and also based on experiences on above-mentioned participants in the world of education, recommendations for improvement of universities, regardless of their financial structure, can be deduced.

\section{Recommendations}

1. All universities should focus on the demand that "the student must be in the center of the new concept of high education, and teachers should be focused on teaching the student" (Kovačević, Vreme br. 1029, 2010). The new concept places the student in the first plane, he/she is the one being educated, and teachers are there to teach him/her.

2. The general goal, besides the number, should be the quality of graduates. On of the manners for achieving that is competition, which is an imminent and good process. Competition should be developed not only between private and state, but also even more between private universities themselves. Competition works directly towards improving quality, because it leads to elimination of bad students and improves average. It also leads to the fact that bad students work harder in order to improve quality and get better.

3. Educational authorities represent a special problem, because they are often not up to their mission when it comes to relation towards high education. State institutions also side with state universities, not understanding that quality is the main determinant, even though they declare that: "The task of the Ministry of education is to achieve a high level of quality of studies at private and state 
universities and to increase the number of people with high education", placing, before everything else, kin the primary plane "teaching staff and its competencies, quality of study programs, quality of students' books, average passage of students and, most importantly, applicability of knowledge, i.e. acceptance of expertise on the market of work force upon graduation" (Žarko Obradović, Vreme, 2010). 4. Ministry documents encompass the ways how to achieve European quality of studies: it is necessary to constantly evaluate and adjust standards with those from the European area of education and to constantly evaluate the quality of work at high education establishments. At the same time, the state must increase funding for high education, infrastructure and equipment. "It is especially important to establish better connection between studies and work market, so that quality could be subject to external evaluation as well" (Žarko Obradović, Vreme, 2010).

5 . There is no valid research which would determine: How many teachers from state universities work at private ones? Evidently, their number is not small at all, which can lead to questioning of validity teachers at state universities as well. Engagement of teaching staff at both universities should be transparent, within inter-university cooperation. This would help both types of universities to exchange more efficiently resources and experiences with the aim of a more quality fulfillment of needs of students and employers. The decision which should be implemented in RS that teachers from state universities can not work at private ones may be of short life (Nezavisne, 2009).

6. It is necessary to work more aggressively towards ensuring quality of work at universities, especially when it comes to the quality of teaching process and grading. To this aim, it is necessary to work on perpetual self-evaluation in all segments of university's work, from the quality of preparation of studying process, transparency and availability to all users, and quality of managing human and material resources, to correct interpretation of principles of Bologna process, binding to all, including firstly teachers and teacher assistants.

\section{Grading of students' results of studying is a} crucial matter in the teaching process. It should be an incentive for students' learning. Research has shown thatatall universities there is self-government in grading students, a bit more prominent at state universities. Students are displeased with their avoidance of planning the grading process, especially when it comes to planning exam schedules which are often constructed (or do not exist at all in some environments) to the damage of students. Even the best students are not capable of studying for two different exams at the same time, or have two difficult exams during two days. This matter requires a bit of good will and establishing mutual trust between students and teachers regarding raising satisfaction in this area to a higher level.

8. This issue is emphasized in principles of Bologna process. Relation toward Bologna is shown in our research as unfavorable for state universities, because students are not sufficiently informed, "interpreting Bologna each in their own way" is in action, and it is more present at state universities. This is why it is necessary for students' organizations to work harder, together with teachers, on detailed informing with Bologna process, and to make clear, generally acceptable strategies for its implementation.

\section{Conducting professional-research work is one} of the important landmarks of quality of work at a university. There is a sensation that in that area 
there are not many who can be commended for this. Rare are the authoritative figures from the academic community who respond to rigorous demands of acclaimed academic institutions in the area of science. In Nezavisne (2009), those in charge emphasize that at this time at 12 private universities in RS six research projects are being worked on, in cooperation with international organizations, and invite colleagues from state universities to say "where exactly and with whom they they conduct such research projects" (Kalinić in: Nezavisne, 2009). The fact that research projects are important as a quality landmark is also confirmed by Radulović (2009) in his paper. He claims that "Quality and prestige of a university, besides accomplished quality in teaching process, is also measured by volume and quality of research" (Radulović, 2010,p.36). This is why all universities, especially state universities, must wake up. They should free themselves from conservative views, rely on their experience, but also on young forces who acquired their knowledge at other universities, turn towards constant improvement of quality of their work, together with their students, cooperate with private universities if there is (and such cases exist) something to learn from them.

10. One of the most important landmarks of quality is the philosophy of constant analysis and improvement of quality in all segments of work at a university, regardless of the nature of ownership. Research has shown that state universities lack a lot more willingness for change which lead to improvement of quality of work. This is visible in section 6. from research results. All examinees at state universities are of the opinion that more must be done on: communication between students and teachers (teacher assistants), application of a wider assortment of teaching methods and modes

of work, implementing clear rules about grading, transparent to everyone from the beginning of the academic year, mutual planning of exam terms and schedules, accessibility of teaching staff towards students, building and empowering pedagogical skills necessary for quality teaching for teaching staff at the university, and employing more forms and manners of grading of students' studying results, also known to everybody.

11. Both types of universities should be turned towards developing plans and programs in the curriculum form, which will, with offered optional areas of study and subjects, enable satisfying the needs of students and work market. In this sense, certain advantage of private universities is evident in a more efficient response to these challenges.

12. Embark, as soon as possible, in the accreditation process, not only in the segment of university organization, but also regarding program studies and courses within departments and universities. The current state of affairs is compromised, without perspective for high education in Bosnia and Herzegovina in the future, because the Agency for development of high education and quality insurance in Bosnia and Herzegovina claims that all universities that were registered by August 2007 acquired temporary accreditations (Fejzić, Nezavisne 2011). So, a space for non-conflict relations and status quo procrastination has been created when it comes to quality of work at universities in all their segments. The issue of accreditations should be separated from politics and serve as incentive for universities to conduct self-evaluation in all segments, as necessary activities in the process of ensuring quality. 


\section{REFERENCES}

- Bošnjak, D. and Mecan, Z. (2008). Bolonjski proces: Borba do posljednjeg studenta [The Bologna Process: Fight to the last student]. www.media. $\mathrm{ba} / \mathrm{mcsonline} / \mathrm{bs} /$ tekst/bolonjski-proces-borba-doposljednjeg-studenta 21.07.2008

- Jovanović, P. (2011). Državni i privatni univerziteti, po čemu (ne)treba da se razlikuju [State and private universities, by which (not) to be different].

- Mehmedić-Džonlić, S. (2011). Privatni $i$ javni univerziteti u BiH Jedni plaćaju ispite a drugi kupuju diplome; svi uče, niko nema para [Private and public universities in BiH. One pays exams while others buy a diplomas; all learn, no one has the money.] http:// www.pulsdemokratije.ba /index.php?id=1990\&l=bs, 01.03.2011.

- Merriam, B. Sharan. 1998. Qualitative Research and Case Study Applications in Education. San Francisssco: Jossey-Bass.

- Mužić, V. 1979. Metodologija pedagoškog istraživanja, IV izdanje, II prerađeno $i$ nadopunjeno izdanje. [Methodology of educational research (IV edition, second revised and supplemented edition]. Sarajevo: IGKRO,,Svjetlost“"

- Mužić, V. (1999). Uvod u metodologiju istraživanja odgoja $i$ obrazovanja [Introduction into research methodology of education]. Zagreb: Educa.

- Mitrović, R. (2011). Problemi privatnih fakulteta [Problems of private universities]. www.studiram.com/ vesti/obrazovanje/150 -problemi-privatnih-fakulteta
- Fejzić, N. and Kalinić, Z. (2009). Dražen Remiković: Ne primaju studente $s$ privatnih fakulteta [They don't accept students from private colleges]. Nezavisne od 20.07.2009.

- http://www.nezavisne.com/dogadjaji/ufokusu/43929/ Ne-primaju-studente-s-privatnih-fakulteta.html, 05.12.2011, 19,34

- PRESS. (2010). Sve veći ugled privatnih fakulteta [The increasing reputation of private universities]. Beograd 20. 09. 2010

- Radulović, J. (2010). Doprinos privatne inicijative $u$ obrazovanju [The contribution of private initiative in education]. Sociološka luča IV/1. Filozofski fakultet Nikšić. Odsjek za sociologiju. Društvo sociologa Crne Gore

- $\quad$ Ristić, Ž. (2006). O istraživanju, metodu i znanju, drugo izdanje [The research, methods and knowledge, second edition]. Beograd: Institut za pedagoška istraživanja.

- Sallis, E. (1996). $2^{\text {th }}$ ed. Total Quality Management in Education. London: Kogan Page LimitedSlovenijezašolstvo

- Vreme, (2010.) Broj 1029 od 23.09.2010. Konferencija »Kvalitet studija na privatnim $i$ državnim fakultetima"[Conference "The quality of studies on private and state universities"]

- Walker, R. (2006). AVM Testing: It Is Not as Daunting as You Might Think. www.facorelogic.com, taken over on 25.08.2010. 